\title{
PENGARUH ORIENTASI KEWIRAUSAHAAN DAN KEUNGGULAN BERSAING TERHADAP KEBERHASILAN USAHA PADA RUMAH MAKAN DENDENG BATOKOK DI PROVINSI JAMBI
}

\author{
Frans A. 1) Dahmiri $^{2)}$, Sigit Indrawijaya ${ }^{3)}$ \\ ${ }^{1,2,3)}$ Prodi Manajemen FEB Univeritas Jambi \\ Azharifrans@gmail.com
}

\begin{abstract}
Abstrak
Penelitian ini bertujuan untuk mengetahui pengaruh orientasi kewirausahaan dan keunggulan bersaing terhadap rumah makan dendeng batokok di provinsi jambi. Populasi dalam penelitian ini adalah pemilik rumah makan dendeng batokok pada tahun 2020, jumlah sampel dihitung berdasarkan Teknik pengambilan sampel yang digunakan adalah metode sampel jenuh yakni sebanyak 37 responden. Pengumpulan sampel dilakukan dengan menyebarkan kuesioner dengan teknik Simple random sampling. Metode analisis data menggunakan metode deskriptif dan metode kuantitatif yaitu analisis regresi linier berganda dengan tingkat signifikan 0,05. Keseluruhan analisis dihitung menggunakan program SPSS versi 25. Hasil dari penelitian menunjukkan, bahwa (1) orientasi kewirausahaan (X1) dan keunggulan bersaing (X2) berpengaruh positif dan signifikan bersama-sama terhadap keberhasilan usaha $(Y)$ rumah makan dendeng batokok di provinsi jambi. (2) keunggulan bersaing merupakan variabel yang paling dominan mempengaruhi keberhasilan usaha rumah makan dendeng batokok di provinsi jambi.
\end{abstract}

Kata Kunci: Orientasi Kewirausahaan, Keunggulan Bersaing, dan Keberhasilan Usaha.

\begin{abstract}
This study aims to determine the effect of entrepreneurial orientation and competitive advantage on the batokok dendeng restaurant in Jambi province. The population in this study were the owners of the batokok beef jerky restaurant in 2020, the number of samples was calculated based on the sampling technique used was the saturated sampling method, namely 37 respondents. The sample was collected by distributing questionnaires with the simple random sampling technique. Methods of data analysis using descriptive methods and quantitative methods, namely multiple linear regression analysis with a significant level of 0.05. The overall analysis was calculated using the SPSS version 25 program. The results of the study showed that (1) entrepreneurial orientation (X1) and competitive advantage (X2) had a positive and significant effect together on the business success $(Y)$ of the batokok beef jerky restaurant in Jambi province (2) competitive advantage is the most dominant variable affecting the success of the batokok beef jerky restaurant business in Jambi province.
\end{abstract}

Keywords: Entrepreneurship Orientation, Competitive Advantage, and Business Success.

\section{PENDAHULUAN}

Melihat keadaan bahwa perkembangan zaman saat ini yang semakin meningkat menjadikan keinginan dan selera konsumen yang semakin tinggi. Lingkungan ekonomi dan kemajuan teknologi yang berubah dengan cepat menuntut setiap pelaku bisnis termasuk industri kecil menengah untuk beradaptasi dengan pola perubahan yang ada untuk mengasilkan produk atau jasa yang dapat diterima oleh konsumen agar suatu industri tetap 
mampu bersaing. Hal ini menyebabkan suatu industri, baik produk atau jasa dituntut untuk meningkatkan kualitas produk, kapasitas produksi dan melakukan inovasi produk sehingga konsumen akan tetap menggunakan produk atau jasa dari industri tersebut.

Kemajuan teknologi yang tidak dapat dibendung maka suatu produk perusahaan akan tambah berkembang sampai pada suatu titik, dimana produk tersebut nantinya akan sulit dibedakan antara satu dengan lainnya. Agar menang dalam suatu persaingan, maka dalam memasarkan produk saat ini produsen tidak hanya berdasarkan pada kualitas produk saja, tetapi juga bergantung pada strategi yang umumnya digunakan perusahaan yaitu orientasi pasar dan inovasi serta orientasi kewirausahaan (Wahyono,2002). Orientasi kewirausahaan merupakan budaya perusahaan yang bisa membawa pada meningkatnya kenerja pemasaran. Orientasi kewirausahaan sebagai budaya organisasi yang paling efektif dan efisien untuk menciptakan perilaku-perilaku yang dibutuhkan untuk menciptakan superior value bagi pembeli dan menghasilkan superior performance bagi perusahaan. Perusahaan yang telah menjadikan orientasi kewirausahaan sebagai budaya organisasi akan berdasar pada kebutuhan dasar eksternal, keinginan dan permintaan pasar sebagai dasar dalam penyusunan strategi bagi masing-masing unit bisnis dalam organisasi, dan menentukan keberhasilan perusahaan.

Pemimpin yang berorientasi wirausaha memiliki visi yang jelas dan berani untuk menghadapi risiko sehingga mampu menciptakan kinerja yang baik. Organisasi dengan tipe wirausaha adalah berhubungan dengan kinerja pemasaran yang tinggi. Perusahaan yang manajer puncaknya adalah wirausahawan ternyata lebih banyak yang kinerjanya tinggi dibandingkan yang para manajer puncaknya bukan wirausahawan. Orientasi kewirausahaan merupakan kemampuan kreatif dan inovatif yang dijadikan dasar, kiat dan sumber daya untuk mencari peluang menuju kesuksesan suatu industri. Pada lingkungan ekonomi yang dinamis ini, orientasi kewirausahaan jelas merupakan hal yang sangat penting bagi kelangsungan suatu industri dalam melakukan inovasi produknya.

Orientasi kewirausahaan merupakan konstruk yang mengintegrasikan kewirausahaan dan manajemen strategik. Manajemen strategik menghendaki agar perusahaan memiliki dan mengekploitasi keunggulan bersaing dalam konteks lingkungan tertentu, pada saat yang sama, kewirausahaan giat berusaha mencari keunggulan bersaing melalui produk, proses, dan inovasi pasar (Kuratko dan Audretsch,2009). Menurut Risnawati dan Noermijati (2008), orientasi kewirausahaan merupakan orientasi strategi perusahaan dalam berwirausaha untuk memperoleh keunggulan kompetitif dengan indikator: pengambilan keputusan, praktek dan metode.

Keunggulan bersaing diartikan sebagai strategi dari perusahaan yang melahkukan kerjasama untuk menciptakan keunggulan bersaing yang lebih efektif dalam pasarnya. Untuk mengukur keunggulan bersaing adalah keunikan, tidak mudah di tiru, dan harga bersaing. Keunikan produk adalah keunikan produk atau barang yang memadukan nilai seni dan dengan selera pelanggan, harga bersaing adalah kemampuan perusahaan untuk menyesuaikan harga produknya dengan harga di pasaran, tidak mudah dijumpai berarti keberadaannya langka dalam persaingan yang saat ini dilahkukan (Riany.A.I. dan Dahmiri, 2020).

Menurut Saiman (2014), keunggulan bersaing diharapkan mampu untuk mencapai laba sesuai rencana, meningkatkan pangsa pasar, meningkatkan kepuasan pelanggan, serta melanjutkan kelangsungan hidup suatu usaha. Menurut Barney (2010) Keunggulan bersaing merupakan strategi keuntungan dari perusahaan yang melakukan kerjasama untuk berkompetisi lebih efektif dalam pasar. Perusahaan mengalami keunggulan bersaing ketika tindakan-tindakan dalam suatu industri atau pasar menciptakan nilai ekonomi dan 
ketika beberapa perusahaan yang bersaing terlibat dalam tindakan serupa.

Pemahaman pasar dapat ditunjukkan dengan kemampuan perusahaan dalam memberikan kepuasan kepada pelanggan, mengenali gerak-gerik pesaing sehingga perusahaan mampu menempatkan pelanggan dan pesaingnya secara harmonis. Dengan memiliki kemampuan dalam penginderaan pasar, maka mampu menciptakan keunggulan bersaing atas produk yang dihasilkanny sehingga mampu meningkatkan kinerja pemasarannya. Dalam melaksanakan penginderaan permintaan selain menjadi peran peningkatan kinerja pemasaran, juga menjadi solusi kunci tulang punggung pengendali permintaan.

Persaingan dalam dunia bisnis merupakan hal yang tidak dapat dihindari. Dengan adanya persaingan, maka usaha dihadapkan pada berbagai peluang dan ancaman baik yang berasal dari luar maupun dari dalam negeri. Untuk itu setiap usaha dituntut untuk selalu mengerti dan memahami apa yang terjadi di pasar dan apa yang menjadi keinginan maupun kemauan konsumen, serta berbagai perubahan yang ada di lingkungan bisnisnya sehingga mampu bersaing dengan perusahaan lainnya. Banyak sekali jalan menuju kesuksesan salah satu diantaranya dengan membuat sebuah cikal bakal bisnis yang diharapkan mampu mengembangkan daya kreativitas dan inovasi. Hal ini sangat membutuhkan keberanian yang luar biasa. Bisnis adalah suatu kegiatan usaha individu yang terorganisasi untuk menghasilkan dan menjual barang dan jasa guna mendapatkan keuntungan dalam memenuhi kebutuhan masyarakat (Hermansyah dan Dahmiri, 2019).

Bisnis makanan merupakan bisnis yang senantiasa bertahan dan terus berkembang seiring dengan meningkatnya kebutuhan kuliner masyarakat, bisnis ini sebagai bisnis yang menjanjikan untuk memberikan keuntungan dan tidak mudah mengalami penurunan karna bisnis ini bukan merupakan bisnis musiman. Pedagang harus memiliki strategi tersendiri untuk bersaing dengan pedagang lainnya, persaingan dalam bisnis sangatlah tinggi karena banyaknya usaha rumah makan yang ada di wilayah provinsi jambi.

Rumah makan dendeng batokok merupakan salah satu produk makanan yang memiliki rasa yang berbeda dengan yang lain, proses pembuatan yang cukup unik dan perlu keahlian khusus, Dendeng batokok tak hanya ada di Sumatra Barat, Di Kota Sungai Penuh dan Kabupaten Kerinci, Provinsi Jambi juga memiliki kuliner dendeng batokok ini. Meski nama sama namun ada perbedaan. Dendeng Batokok merupakan salah satu kuliner istimewa masyarakat Kerinci, Provinsi Jambi. Masakan berbentuk pipih ini begitu nikmat disantap jika dibaluri cabe merah pedas segar. Dendeng Batokok dapat anda temui di Rumah makan dendeng batokok yang tersebar di seluruh Provinsi Jambi.

Bahan baku Dendeng Batokok biasanya berasal dari daging sapi, namun ada juga yang menggunakan daging kerbau sebagai bahan utama membuat Dendeng. Batokok dalam bahasa Kerinci artinya dipukul-pukul. Di sebut Dendeng Batokok dikarenakan sebelum dipanggang di atas bara arang tempurung kelapa, lalu dilumuri minyak kelapa, daging yang sudah di bumbui akan di tokok atau di pukul- pukul pelan agar pipih dengan menggunakan palu atau batu khusus. Inilah salah satu rahasianya sehingga daging nya matang sempurna dan tidak alot. Dendeng Batokok ini rasanya enak dan segar, Daging yang sudah ditumbuk akan lebih mudah menyerap bumbu masakan yang dilumuri saat pemanggangan. Masakan ini sangat cocok dimakan bersama nasi dari beras payo yang merupakan jenis padi lokal Kerinci. Meski hampir mirip dengan Dendeng Batokok Sumatera Barat, namun secara tekstur dan rasa sangat jauh berbeda. Dendeng Batokok Sumatera Barat bertekstur kering dan gurih, sedangkan Dendeng Batokok khas Kerinci agak basah dan lembut. Dendeng tidak banyak bumbu dalam pengolahannya, namun proses perendaman di air kelapa turut memunculkan rasa gurih pada daging. Cara 
menyantap dendeng batokok ini dengan menuangkan sambal dendeng yang berasa masam pedas atau bisa juga sambal kecap. Dijamin cita rasa dendeng batokok ini akan membuat yang menyukai olahan daging akan ketagihan, Paling enak makan dendeng batokok nasinya beras Payo asli Kerinci. Dendeng merupakan salah satu produk olahan daging tradisional yang sudah dikenal oleh masyarakat luas, dan umumnya terbuat dari daging sapi. Dendeng mempunyai kandungan protein yang tinggi, selain itu dalam dendeng terdapat beberapa kandungan mineral seperti kalsium, fosfor, dan besi yang dapat memperbaiki gizi masyarakat. Dendeng memiliki ciri yang khas, yaitu berwarna cokelat kemerahan, tipis dan flavornya yang sedap. Pembuatan dendeng merupakan salah satu alternatif pengolahan daging sapi yang dapat memperpanjang umur simpan.

Di provinsi jambi memiliki potensi cukup baik dalam mengembangkan berbagai hasil industri terutama usaha mikro, kecil dan menengah dalam memanfaatkan bahan baku lokal dan tenaga kerja yang ada didalam provisi jambi sehingga dapat mengembangkan program padat karya dalam mengurangi angka penganguran dan kemiskinan di provinsi jambi.

\section{Tujuan Penelitian}

1. Mengetahui pengaruh orientasi kewirausahaan dan keunggulan bersaing terhadap keberhasilan dalam menjalankan usaha rumah makan.

2. Mengetahui orientasi kewirausahaan dan keunggulan bersaing yang paling dominan mendorong wirausaha meraih keberhasilan usaha Rumah makan.

\section{TINJAUAN PUSTAKA}

\section{Kewirausahaan}

Kewirausahaan (Enterpreneurship) adalah usaha kreatif yang dibangun berdasarkan inovasi untuk menghasilkan sesuatu yang baru, memiliki nilai tambah, memberi manfaat, menciptakan lapangan kerja dan hasilnya berguna bagi orang lain. (Eddy S. Soegoto, 2014). Kewirausahaan adalah proses dinamis dari visi, perubahan dan penciptaan yang mensyaratkan aplikasi energi dan semangat terhadap penciptaan dan implementasi dari ide baru dan solusi kreatif (Kuratko, 2009).

\section{Pengertian wirausaha}

Menurut Eddy Soeryanto Soegoto (2014) wirausaha (entrepreneur) adalah orang yang berjiwa kreatif, inovatif, mandiri, ulet, dan tekun, rajin, disiplin, siap menghadapirisiko, Jeli melihat dan meraih peluang, piawai mengelola sumber daya, dalam membangun, mengembangkan, memajukan dan menjadikan usaha atau perusahaannya unggul.

Menurut Hendro (2011) wirausaha melakukan sebuah proses yang disebut creative destruction untuk menghasilkan suatu nilai tambah (added value) guna menghasilkan nilai yang lebih tinggi. Untuk itu keterampilan wirausaha (entrepreneurial skill) berintikan kreativitas. Wirausaha itu memiliki banyak padanan kata. Wirausaha dibagi menjadi dua kata yaitu wira dan usaha, wira yang diartikan berani, pejuang, gagah dan usaha diartikan usaha jadi wirausaha yaitu berani usaha sendiri. Pengusah orang yang mengusahakan suatu pekerjaan atau usahawan

\section{Orientasi Kewirausahaan}

Orientasi kewirausahaan merupakan konstruk yang mengintegrasikan kewirausahaan dan manajemen strategik. Manajemen strategik menghendaki agar perusahaan memiliki dan mengekploitasi keunggulan bersaing dalam konteks lingkungan 
tertentu, pada saat yang sama, kewirausahaan giat berusaha mencari keunggulan bersaing melalui produk, proses, dan inovasi pasar (Kuratko dan Audretsch, 2009). Menurut Risnawati dan Noermijati (2008), orientasi kewirausahaan merupakan orientasi strategi perusahaan dalam berwirausaha untuk memperoleh keunggulan kompetitif dengan indikator: pengambilan keputusan, praktek dan metode.

\section{Keunggulan Bersaing}

Keunggulan bersaing merupakan strategi keuntungan dari perusahaan yang melakukan kerjasama untuk berkompetisi lebih efektif dalam pasar. Perusahaan mengalami keunggulan bersaing ketika tindakan-tindakan dalam suatu industri atau pasar menciptakan nilai ekonomi dan ketika beberapa perusahaan yang bersaing terlibat dalam tindakan serupa (Barney,2010). Keunggulan bersaing dianggap sebagai keuntungan dibanding kompetitor yang diperoleh dengan menawarkan nilai lebih padakonsumen dibanding penawaran kompetitor (Kotler, 2009). Keunggulan bersaing diharapkan mampu untuk mencapai laba sesuai rencana, meningkatkan pangsa pasar, meningkatkan kepuasan pelanggan, serta melanjutkan kelangsungan hidup suatu usaha (Saiman,2014).

\section{Keberhasilan usaha}

Menurut Ina Primiana (2009) mengemukakan bahwa keberhasilan usaha adalah permodalan sudah terpenuhi, penyaluran yang produktif dan tercapainya tujuan organisasi. Sedangkan menurut Algifari (2003) ia berpendapat bahwa keberhasilan usaha dapat dilihat dari efisiensi proses produksi yang dikelompokkan berdasarkan efisiensi secara ekonomis. Henry Faizal Noor (2007) mengemukakan bahwa Keberhasilan usaha pada hakikatnya adalah keberhasilan dari bisnis mencapai tujuanya, suatu bisnis dikatan berhasil bila mendapatkan laba, karena laba adalah tujuan dari seseorang melakukan bisnis. Menurut Suryana (2011) yang mengemukakan bahwa faktor yang merupakan tujuan yang kritis dan menjadi ukuran dari keberhasilan suatu perusahaan adalah laba.

\section{METODE PENELITIAN}

Jenis penelitian yang digunakan dalam penelitian ini adalah penelitian deskriptif dengan metode kuantitatif dengan menggunakan kuesioner sebagai pengumpulan data. Populasi dalam penelitian ini adalah pemilik rumah makan dendeng batokok di provinsi jambi. Teknik pengambilan sampel menggunakan sampel jenuh atau sensus dengan jumlah sampel sebanyak 37 orang. Teknik pengumpulan data menggunakan kuesioner yang telah diuji validitas dan reliabilitasnya. Teknik analisis data yang digunakan adalah regresi berganda.

\section{HASIL PENELITIAN DAN PEMBAHASAN Uji Asumsi Klasik}

Uji normalitas bertujuan untuk menguji apakah dalam model regresi, variable penggangu atau residual memiliki distribusi normal. Dalam penelitian ini di gunakan OneSample Kolmogrov-Smirnov Test dengan menggunakan taraf signifikansi nilai residual dari persamaan regresi lebih besar dari 5\% atau 0,05. Dari hasil analisis nilai K-S sebesar 0,115 dengan nilai signifikansi 0,200 yang berarti nilai residual terdistribusi secara normal atau memenuhi asumsi klasik karena nilai asymp sig lebih besar daripada 0,05 (0,200> $0,05)$.

Uji multikolinieritas dilakukan untuk menguji apakah pada model regresi ditemukan adanya korelasi antara variable independen. Pengujian multi kolinearitas di lakukan dengan 
cara melihat nilai tolerance dan nilai Varian Inflation Faktor (VIF). Apabila nilai tolerance di atas 0,10 atau VIF di bawah 10, maka model regresi tidak terdapat multikolinieritas. Keempat variable independen memiliki nilai Tolerance Value diatas 0,1 dan VIF kurang dari 10. Jadi dapat disimpulkan bahwa tidak ada multikolinieritas antar variable independen (Orientasi Kewirausahan dan Keunggulan bersaing) dalam model regresi.

Ghozali (2013) menyebutkan bahwa pengujian ini dilakukan untuk menguji apakah dalam satu model regresi linear ada tidaknya korelasi antara variable pengganggu pada periode t1 (sebelumnya). Auto korelasi muncul karena observasi yang berurutan sepanjang waktu berkaitan satu sama lain. Masalah ini timbul karena residual tidak bebas dari satu variable ke variable lainnya. Untuk mendeteksi ada atau tidaknya auto korelasi digunakan uji Durbin Watson Test (DW test) sebagai pengujinya dengan taraf signifikansi (L) $=5 \%$. Hasil uji autokorelasi pada tabel di atas menunjukan bahwa nilai Durbin- Waston (D-W) untuk variable Keberhasilan usaha dengan menggunakan nilai signifikansi 5\%, jumlah pengamatan 37 adalah sebesar 1.699 Nilai Durbin-Waston tersebut berada di antara batas atas (4-du) dan batas bawah (4-dl), maka dapat di simpulkan bahwa model regresi linear berganda tidak terjadi gejala autokorelasi.

Uji heteroskedastisitas bertujuan untuk menguji apakah dalam model regresi terjadi ketidaksamaan variance dan residual satu pengamatan ke pengamatan yang lain (Ghozali dalam Andriani, 2016) model regresi yang baik adalah yang homoskedastisitas atau tidak terjadi heteroskedastisitas. Salah satu cara untuk mendeteksinya ada atau tidaknya heteroskedastisitas adalah dengan menggunakan grafik scatterplot. Jika titik-titik membentuk pola tertentu yang teratur (bergelombang, melebar, kemudian menyempit) di indikasikan terjadi heteroskedastisitas. Jika tidak ada pola yang jelas dan titik menyebar di atas dan di bawah angka 0 pada sumbu Y, di indikasikan tidak terjadi heteroskedastisitas. Berdasarkan analisis grafik Scatterplot di atas terlihat bahwa titik- titik menyebar secara acak dan tidak membentuk suatu pola tertentu serta tersebar baik di atas maupun di bawah angka 0 pada sumbu Y. Dengoiuan demikian dapat di simpulkan model regresi ini tidak terjadi heteroskedastisitas.

\section{Analisis Regresi Linier Berganda}

Analisis regresi linear berganda digunakan dalam penelitian ini bertujuan untuk membuktikan hipotesis mengenai adanya pengaruh positif dan signifikan antar variabell. Perhitungan statistic dalam analisis regresi linear berganda yang digunakan dalam penelitian ini adalah menggunakan bantuan program SPSS for windows versi 25.0. Hasil pengolahan data dapat dilihat mealui tabel berikut:

Tabel 4. Hasil Uji Regresi Linear Berganda Coefficients $^{a}$

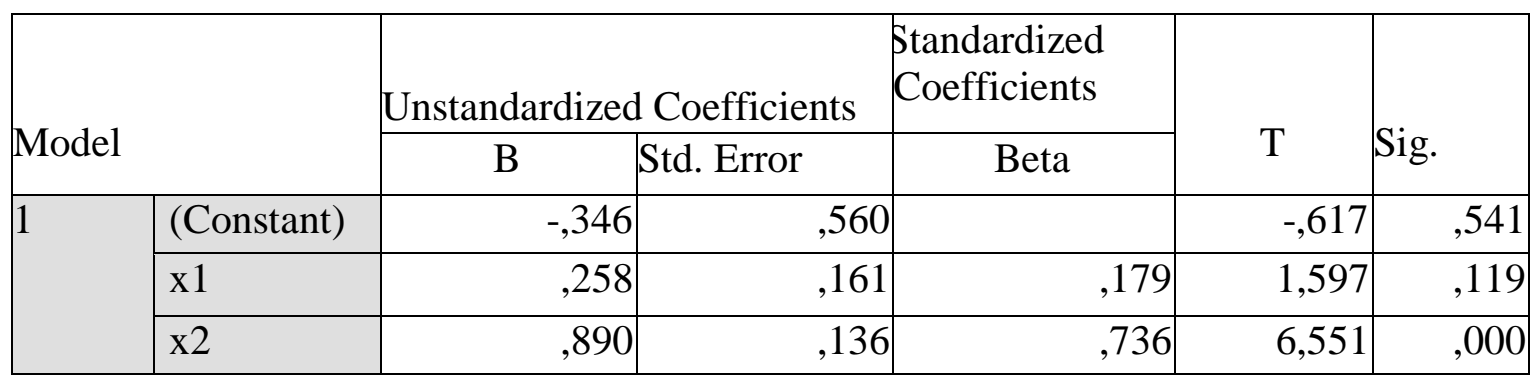

a. Dependent Variable: y

Sumber: Hasil Pengolahan Data SPSS 25 Tahun 2020 
Berdasarkan keterangan diatas pada tabel maka diperoleh persamaan regresi berikut:

Dari persamaan regresi diatas dapat diartikan sebagai berikut:

$$
Y=-0,346+0,258 X_{1}+0.890 X_{2}+e
$$

1. Konstanta sebesar -0,346 ini berarti jika semua variable independen (Orientasi Kwirausahaan dan Keunggulan) dianggap sama dengan nol maka secara konstan Keberhasilan usaha sebesar -0,346.

2. Koefisien regresi variabel Orientasi Kewirausahaan (X1) sebesar 0.258 dan bertanda positif terhadap Keberhasilan Berusaha, artinya setiap terjadi peningkatan variable orientasi Kewirausahaan sebesar satu satuan Keberhasilan usaha akan meningkat sebesar 0.258 .

3. Koefisien regresi variable Keunggulan Bersaing (X2) sebesar 0.890 dan bertanda positif terhadap Keberhasilan Usaha, artinya setiap terjadi peningkatan variabel Keunggulan Bersaing sebesar satu satuan maka Keberhasilan Usaha akan meningkat sebesar 0.890 .

\section{Uji Hipotesis Uji f}

Hasil uji F dalam penelitian ini dapat dilihat pada tabel berikut:

Tabel 5 Hasil Uji F

ANOVA $^{\mathrm{a}}$

\begin{tabular}{|l|l|r|r|r|r|l|}
\hline Model & Sum of Squares & Df & Mean Square & F & Sig. \\
\hline 1 & Regression & 5,182 & 2 & 2,591 & 47,702 &, $000^{\mathrm{b}}$ \\
\cline { 2 - 8 } & Residual & 1,847 & 34 &, 054 & & \\
\cline { 2 - 7 } & Total & 7,028 & 36 & & & \\
\hline
\end{tabular}

a. Dependent Variable: $y$

b. Predictors: (Constant), x1, x2

Dari tabel diatas dapat dilihat bahwa p-value $(0,000)<\alpha(0,05)$. Hal ini berarti $\mathrm{H} 0$ ditolak dan $\mathrm{Ha}$ diterima, sehingga dapat disimpulkan bahwa variable Orientasi Kewirausahaan (X1) dan Keunggulan Bersaing (X2) mempunyai pengaruh positif dan signifikan secara bersama-sama terhadap variable dependen Keberhasilan Usaha (Y).

Uji t

Hasil uji T dalam penelitian ini dapat dilihat pada tabel berikut:

Tabel 6 Hasil Uji t

Coefficients $^{\mathrm{a}}$

\begin{tabular}{|c|c|c|c|c|c|c|}
\hline \multirow{2}{*}{\multicolumn{2}{|c|}{ Model }} & \multicolumn{2}{|c|}{ Unstandardized Coefficients } & \multirow{2}{*}{\begin{tabular}{|c}
$\begin{array}{l}\text { Standardized } \\
\text { Coefficients }\end{array}$ \\
Beta
\end{tabular}} & \multirow[b]{2}{*}{$\mathrm{t}$} & \multirow[b]{2}{*}{ Sig. } \\
\hline & & \begin{tabular}{c|c}
$\mathrm{B}$ & $\mathrm{s}$
\end{tabular} & Std. Error & & & \\
\hline \multirow[t]{3}{*}{1} & (Constant) &,- 346 & ,560 & &,- 617 & ,541 \\
\hline & $\mathrm{x} 1$ & ,258 &, 161 &, 179 & 1,597 & ,119 \\
\hline & $\mathrm{x} 2$ & ,890 & ,136 & ,736 & 6,551 &, 000 \\
\hline
\end{tabular}

a. Dependent Variable: y

Sumber: Data diolah menggunakan SPSS.25, 2020 
Uji $\mathrm{t}$ ini digunakan untuk menjawab hipotesis pertama dan kedua $\left(\mathrm{H}_{0}\right.$ dan $\left.\mathrm{H}_{\mathrm{a}}\right)$. Pengujian dilakukan dengan membandingkan tingkat signifikan dengan derajat kesalahan 5\% (0.05). Apabila tingkat signifikan $t_{\text {value }}<0.05$ maka variable independen memberikan pengaruh positif terhadap variable dependen.

Berikut merupakan hasil uji t yang telah dilakukan:

1. Orientasi Kewirausahaan $\left(\mathrm{X}_{1}\right)$

Berdasarkan pengujian yang telah dilakukan variable ini memiliki tingkat signifikan sebesar 0.119 yang apabila dibandingkan dengan tingkat kesalahan 5\% atau 0.05 variabel signifikan karena lebih besar dari nilai kesalahan Artinya $\mathrm{H}_{\mathrm{a}}$ ditolak berarti variabel Orientasi Kewirausahaan tidak berpengaruh secara parsial terhadap Keberhasilan Usaha.

2. Keunggulan Bersaing $\left(\mathrm{X}_{2}\right)$

Berdasarkan pengujian yang telah dilakukan variable ini memiliki tingkat signifikan sebesar 0.000 yang apabila dibandingkan dengan tingkat kesalahan 5\% atau 0.05 variabel signifikan karena lebih kecil dari nilai kesalahan. Artinya $\mathrm{H}_{0}$ ditolak berarti variabel keunggulan bersaing berpengaruh positif dan signifikan secara parsial terhadap terhadap Keberhasilan Usaha.

\section{KoefisienDeterminasi $\left(\mathbf{R}^{\mathbf{2}}\right)$}

Analisis koefisien determinasi digunakan untuk mengetahui kemampuan variable independen dalam menjelaskan variable dependen. Hasil analisis koefisien determinasi pada penelitian ini dapat di lihat pada tabel 5.16 berikut:

Tabel 7. Hasil Uji Koefisien Determinasi

Model Summary

\begin{tabular}{|c|c|c|c|c|}
\hline Model & $\mathrm{R}$ & R Square & Adjusted R Square & $\begin{array}{l}\text { Error of the } \\
\text { Estimate }\end{array}$ \\
\hline 1 & $859^{\mathrm{a}}$ &, 737 &, 722 & 23305 \\
\hline
\end{tabular}

a. Predictors: (Constant), x1 x.2

Dari hasil perhitungan dengan menggunakan IBM SPSS 25 pada pengolahan data diperoleh nilai koefesien determinasi $\left(r^{2}\right) 0,737$ atau $73,7 \%$. Hal ini menunjukan bahwa persentase sumbangan pengaruh variabel independent (Orientasi Kewirausahaan dan Keunggulan Bersaing) terhadap variable dependen (Keberhasilan Usaha) sebesar 73,7\% sedangkan sisanya sebesar 26,3\% dipengaruhi oleh variabel-variabel lainnya yang tidak terdapat dalam model penelitian ini.

\section{Pembahasan}

\section{Pengaruh orientasi kewirausahaan terhadap keberhasilan usaha}

Orientasi kewirausahaan merupakan variabel bebas yang diteliti dan diuji. Hasil dari penerapan orientasi kewirausahaan ini menurut keberhasilan usaha di rumah makan dendeng batokok di provinsi jambi masuk dalam kategori tinggi. Dapat dilihat bahwa responden rata-rata menyatakan setuju bahwa usaha rumah makan dendeng batokok di provinsi jambi ini memiliki tingkat orientasi kewirausahaan yang tinggi yaitu mampu 
meninngkatkan otonomi, inovasi, kemampuan mengambil resiko, proaktif, dan agresivitas dalam bersaing sehingga menjadikannya sebagai rumah makan yang berhasil dalam usaha.

Dengan demikian, untuk dapat terus menjadi rumah makan yang lebih berhasil dari para pesaing usaha sejenis lainnya, rumah makan dendeng batokok di provinsi jambi harus meningkatkan orientasi kewirausahaan. Cara meningkatkan orientasi kewirausahaan tersebut dengan meningkatkan setiap indikatornya.

Berdasarkan hasil pengujian signifikasi parameter individual (uji statistic t) yang telah dilakukan variable ini memiliki tingkat signifikan sebesar 0,119 yang apabila dibandingkan dengan tingkat kesalahan 5\% atau 0,05 variabel signifikan karena lebih besar dari nilai kesalahan Artinya $\mathrm{H}_{\mathrm{a}}$ ditolak berarti variabel Orientasi Kewirausahaan tidak berpengaruh secara parsial terhadap Keberhasilan Usaha.

\section{Pengaruh Keunggulan Bersaing Terhadap Keberhasilan Usaha}

Keunggulan bersaing merupakan variabel bebas yang diteliti dan diuji. Hasil dari penerapan keunggulan bersaing ini menurut keberhasilan usaha di rumah makan dendeng batokok di provinsi jambi masuk dalam kategori tinggi. Dapat dilihat bahwa responden rata-rata menyatakan setuju bahwa usaha rumah makan dendeng batokok di provinsi jambi ini memiliki tingkat keunggulan bersaing yang tinggi yaitu mampu meninngkatkan keunikan produk, kualitas produk, dan harga bersaing sehingga menjadikannya sebagai rumah makan yang berhasil dalam usaha.

Dengan demikian, untuk dapat terus menjadi rumah makan yang lebih berhasil dari para pesaing usaha sejenis lainnya, rumah makan dendeng batokok di provinsi jambi harus meningkatkan Keunggulan bersaing. Cara meningkatkan Keunggulan bersaing tersebut dengan meningkatkan setiap indikatornya.

Berdasarkan hasil pengujian signifikasi parameter individual (uji statistic t) pengujian yang telah dilakukan variable ini memiliki tingkat signifikan sebesar 0,000 yang apabila dibandingkan dengan tingkat kesalahan 5\% atau 0,05 variabel signifikan karena lebih kecil dari nilai kesalahan. Artinya $\mathrm{H}_{0}$ ditolak berarti variabel keunggulan bersaing berpengaruh positif dan signifikan secara parsial terhadap terhadap Keberhasilan Usaha.

\section{Pengaruh Orientasi Kewirausahaan Dan Keunggulan Bersaing Terhadap Keberhasilan Usaha}

Keberhasilan usaha merupakan variabel terikat yang diteliti dan diuji. Hasil penelitian ini menunjukkan bahwa adanya pengaruh Pengaruh Orientasi Kewirausahaan dan Keunggulan bersaing terhadap keberhasilan usaha pada rumah makan dendeng batokok di provinsi jambi. Penerapan Orientasi Kewirausahaan secara bersama-sama merupakan perpaduan yang baik untuk menjadikan sebuah usaha rumah makan berhasil dari pada pesaing usaha sejenis lainnya. Orientasi Kewirausahaan dan keunggulan bersaing menjadi salah satu cara rumah makan dendeng batokok di provinsi Jambi agar usahanya lebih berhasil dari pada usaha sejenis lainnya, sehingga rumah makan dendeng batokok di provinsi Jambi diminati banyak konsumen.

Sebagaimana diungkapkan sebelumnya, Orientasi Kewirausahaan tidak berpengaruh secara parsial terhadap Keberhasilan Usaha dan Keunggulan berpengaruh secara positif dan signifikan terhadap keberhasilan usaha. Berdasarkan hasil pengujian signifikasi parameter secara keseluruhan (uji statistic f) pada tabel output seperti yang penulis tampilkan pada Tabel 5.19. Dari tabel 5.19 tersebut dapat dilihat bahwa p-value $(0,000)<$ $\alpha(0,05)$. Hal ini berarti $\mathrm{H}_{0}$ ditolak dan $\mathrm{H}_{\mathrm{a}}$ diterima, sehingga dapat disimpulkan bahwa 
variable Orientasi Kewirausahaan (X1) dan Keunggulan Bersaing (X2) mempunyai pengaruh positif dan signifikan secara bersama-sama terhadap variable dependen Keberhasilan Usaha (Y)

\section{Variabel Yang Dominan Antara Orientasi Kewirausahaan Dan Keunggulan Bersaing}

Dapat dilihat variabel orientasi kewirausahaan hasil pengujian hipotesis secara parsial menunjukkan tingkat signifikansi dan besarnya pengaruh orientasi kewirausahaan secara parsial terhadap keberhasilan usaha adalah 0,179 atau 17,9\%. Artinya orientasi kewirausahaan mampu mempengaruhi keberhasilan usaha sebesar 17,9\%. Sedangkan variabel keunggulan bersaing, dapat dilihat dari hasil pengujian hipotesis secara parsial yang menunjukkan tingkat signifikansi dan besarnya pengaruh keunggulan bersaing secara parsial terhadap keberhasilan usaha adalah 0,736 atau 73,6\%. Artinya keunggulan bersaing mampu mempengaruhi keberhasilan usaha sebesar 73,6\%. Sehingga dapat disimpukan berdasarkan hasil uji parsial variabel yang lebih dominan antara orientasi kewirausahaan (X1) dan keunggulan bersaing (X2) adalah keunggulan bersaing (X2). Dapat dilihat besarnya pengaruh keunggulan bersaing terhadap keberhasilan usaha lebih tinggi dari orientasi kewirausahaan.

\section{SIMPULAN DAN SARAN}

\section{Simpulan}

1. Variabel orientasi kewirausahaan (X1) dan keunggulan bersaing (X2) berpengaruh positif dan signifikan bersama-sama terhadap keberhasilan usaha (Y) rumah makan dendeng batokok di provinsi jambi.

2. Berdasarkan uji $\mathrm{t}$ pengujian yang telah dilakukan variable ini memiliki tingkat signifikan sebesar 0.119 yang apabila dibandingkan dengan tingkat kesalahan 5\% atau 0.05 variabel signifikan karena lebih besar dari nilai kesalahan Artinya $\mathrm{H}_{\mathrm{a}}$ ditolak berarti variabel Orientasi Kewirausahaan tidak berpengaruh secara parsial terhadap Keberhasilan Usaha, sedangkan variabel keunggulan bersaing Berdasarkan pengujian yang telah dilakukan variable ini memiliki tingkat signifikan sebesar 0.000 yang apabila dibandingkan dengan tingkat kesalahan 5\% atau 0.05 variabel signifikan karena lebih kecil dari nilai kesalahan. Artinya $\mathrm{H}_{0}$ ditolak berarti variabel keunggulan bersaing berpengaruh positif dan signifikan secara parsial terhadap terhadap Keberhasilan Usaha

3. Variabel keunggulan bersaing merupakan variabel yang paling dominan mempengaruhi keberhasilan usaha. Dapat dilihat besarnya pengaruh keunggulan bersaing terhadap keberhasilan usaha lebih tinggi dari kreativ, besarnya pengaruh keunggulan bersaing sebesar 73,6\% sedangkan orientasi kewirausahaan sebesar 17,9\% terhadap keberhasilan usaha.

4. Dilihat dari analisis Uji Koefisien Determinan (R2), menunjukan bahwa persentase sumbangan pengaruh variabel independent (Orientasi Kewirausahaan dan Keunggulan Bersaing) terhadap variable dependen (Keberhasilan Usaha) sebesar 73,7\% sedangkan sisanya sebesar $26,3 \%$ dipengaruhi oleh variabel- variabel lainnya yang tidak terdapat dalam model penelitian ini.

\section{Saran}

Berdasarkan hasil penelitian bahwa variabel orientasi kewirausahaan berpengaruh lebih rendah terhadap keberhasilan usaha dibandingkan keunggulan bersaing, oleh karena itu hendaknya orientasi kewirausahaan lebih dapat ditingkatkan lagi dengan cara 
meningkatkan otonomi, inovasi, kemampuan mengambil resiko, proaktif, dan agresivitas dalam bersaing

Kepada peneliti selanjutnya yang akan meneliti dengan permasalahan yang sama disarankan agar dapat memilih subjek penelitian dengan karakteristik yang berbedadan menggali variabel-variabel lain yang memiliki pengaruh terhadap keberhasilan usaha dalam berwirausaha. Variabel-variabel lain tersebut seperti kualitas pelayanan, motivasi, harga, brand image, kreativitas, inovasi dan masih banyak variabel-variabel lainnya. Karena hasil dari penelitian tersebut nantinya dapat memperlengkapi informasi yang akan berguna bagi bidang akademik dan memberikan sumbangan besar bagi ilmu pengetahuan

\section{DAFTAR PUSTAKA}

Algifari, (2003). Ekonomi Mikro Teori dan Kasus, Edisi ke-1, cetakan pertama, Bagian Pener-bitan Sekolah Tinggi Ilmu Ekonomi YKPN, Yogyakarta.

Barney, J. B. (2010). Gaining and Sustaining Competitive Advantage, Fourth Edition. Addison Wesley, Massachusetts.

Ghozali, Imam. 2011. Aplikasi Analisis Multivariate dengan Program IBM SPSS (edisi kelima). Universitas Diponegoro. Semarang [Skripsi]

Journal of Business \& Economics. July-December. Pp. 222-233 Hendro. (2011). Dasardasar Kewirausahaan. Erlangga.

Henry Faizal, Noor.(2007). Ekonomimanajerial. Jakarta: PT Raja Grafindo Persada

Hermansyah dan Dahmiri (2019). Analisis Faktor-Faktor Yang Mempengaruhi Keberhasilan Berwirausaha Industri Percetakan (Studi Kasus Wirausaha Industri Percetakan Di Kota Jambi) Jurnal Manajemen Terapan Dan Keuangan Vol. 8. No.3.

Ina Primiana (2009). Mengerakan sector riil UKM dan industry. Bandung: Alfabeta.

Kotler, Philip, dan Keller Kevin Lane. (2007a). Prinsip-Prinsip Pemasaran. Jakarta: Erlangga.

Kuratko, D.F. (2009). Entrepreneurship, Theory, Process, Practice. South-Western: SouthWestern Cengage Learning.

Kuratko, D.F., \&Audretsch, D.B. (2009). Strategic entrepreneurship: exploring different perspectives of an emerging concept. Entrepreneurship Theory and Practice,1:1-17.

Risnawati dan Noermijati. (2008). Pengaruh Orientasi Kewirausahaan terhadap Kinerja Organisasi Koperasi: Orientasi Pasar sebagai Variabel Intervening (Studi pada Koperasi Primer di kota Palu, Sulawesi Tengah) dalam Jurnal Aplikasi Manajemen Vol 9. No.3.

Riany.A.I. dan Dahmiri (2020). Pengaruh Kreativitas Dan Inovasi Terhadap Keunggulan Bersaing (Studi Kasus Wedding Organizer Hastina Puspita Decoration Kota Jambi) Jurnal Manajemen Terapan dan Keuangan (Mankeu) Vol. 9 No. 01.

Saiman, L. (2014). Kewirausahaan (Teori, Praktik, dan Kasus-kasus), edisi kedua. Salemba Empat, Jakarta

Suryana. 2011, Kewirausahaan, Jakarta: Salemba Empat.

Soegoto, Eddy Soeryanto. Enterpeneurship: menjadi Pebisnis Ulung, Edisi Revisi. Elex Media Komputindo, (2014).

Wahyono. (2002). "Orientasi Pasar dan Inovasi: Pengaruhnya Terhadap Kinerja Pemasaran”. Jurnal Sains Pemasaran Indonesia. Vol.1, No.1, Mei. 